\title{
An audit of how patients get on to antiretroviral therapy in Malawi, and the weight gain they experience in the first six months
}

\section{T Bizuwork', SD Makombe ${ }^{2}$, K Kamoto ${ }^{2}$, M Hochgesang ${ }^{3}$, AD Harries ${ }^{2,4,5}$}

1. Zomba Central Hospital, Zomba, Malawi

2. HIV Unit, Ministry of Health, Lilongwe, Malawi

3. U.S. Centers for Disease Control and Prevention, Malawi Country Office

4. Family Health International, Malawi office, Lilongwe, Malawi

5. London School of Hygiene and Tropical Medicine, London, UK

Coressponding author: Professor AD Harries, Family Health International, Malawi Country Office, Arwa House, 3rd Floor, PO Box 30455, Lilongwe 3, Malawi Fax: + 2651774307 Email: adharries@malawi.net

\section{Summary}

An operational study was conducted in 6 public sector health facilities in the Southern Region of Malawi to determine a) drop-out rates during the referral process of patients to antiretroviral therapy (ART) and b) weight gained during the first 6 months in patients who were alive and on ART at that time. There were 738 adult HIV-infected eligible patients booked for group counseling, of whom $550(74.5 \%)$ attended individual counseling and started ART. 16\% of patients dropped out between booking and group counseling and $9.5 \%$ between group counseling and start of ART. In patients who were alive and on ART 6 months after starting, there was a gradual increase in weight with a mean gain of 6.0 $\mathrm{kg}$ in men and $5.0 \mathrm{~kg}$ in women. There was a slight increase in weight gain in patients in WHO Clinical Stage 3 and 4 compared with those in Stage 1\&2, although this was only significant at 6-months between women in Stage 4 compared with women in Stage $1 \& 2(\mathrm{p}<0.05)$. More information is needed on why patients drop out of the counseling process before starting ART, and whether weight gain is a marker for survival in the early months of ART.

\section{Introduction:}

Malawi is making good progress with scaling up antiretroviral therapy (ART) for its HIV-infected eligible patients, and by December 2006, a total of 81,821 patients had started treatment from 103 public sector facilities ${ }^{1}$. HIV-infected patients who are eligible for ART are asked to attend a group counseling session, preferably with a guardian or family member, following which they return one week later for individual counseling and start of $\mathrm{ART}^{2}$. Once patients start ART, they usually do well and start to gain weight

We have no data in the country about a) the drop-out rates between referral for group counseling to individual counseling to start of ART or b) the weight change experienced by patients in the first six months of treatment. We therefore conducted an audit in the Southern Region of Malawi to assess the drop-out rates during the referral process to ART and the amount of weight gained during the first 6 months.

\section{Methods}

\section{Background}

The process of staging patients, the preparatory counseling before starting ART and the follow-up of patients on ART have already been described ${ }^{2}$. In brief, adults and children are eligible for ART if they have a positive HIV test, they or their guardians understand the implications of therapy, and they are assessed in WHO Clinical Stage 3 or 4 or have a CD4-lymphocyte count $<250$ cells $/$ uL for adults and below the threshold value for children ${ }^{3}$. Once a patient is staged as eligible for ART, he/she is asked to return to the clinic with a guardian or family member to attend a group counseling session, at which the principles and practice of ART are presented and discussed by an ART clinician or nurse. At the time of the assessment for ART eligibility, a list of names is made for patients to attend group counseling and at the group counseling session another list of names is made of those who attend. Group counseling sessions normally take about one hour. Following this, the patient is asked to return to the clinic, usually about one week later, for individual counseling and start of ART.

Patients are treated with a generic, fixed dose combination therapy (stavudine, lamivudine, nevirapine), which is dispensed from the ART clinic ${ }^{3}$. In some of the ART clinics, a nutritional supplement is given at the time of starting ART: this consists of "plumpy nut", and is given to patients with a body mass index $<17$.0. Patients are seen at two weeks after ART initiation and then routinely every month for clinical assessment and ART-dispensing. The weight of the patient is measured in $\mathrm{kg}$ at the start of ART and every month during follow-up, and the result is recorded in the ART Patient Treatment Master cards which are kept securely and confidentially in the ART clinic.

Standardised monthly outcomes are recorded in the ART master cards. If the patient experiences an adverse outcome, such as death, default, stop therapy or transfer out to another site, this outcome along with the date, is recorded in the ART master card and ART Register. Treatment outcomes are validated every three months through quarterly supervision visits conducted by the HIV Unit and its partners ${ }^{4}$.

\section{Data collection and analysis}

The present study was carried out in the Southern Region of Malawi. Six facilities in the public sector were selected to be representative of the facilities delivering ART in the country:- one central hospital, one district hospital, one mission hospital, one police hospital, one health center and one clinic. All these facilities were visited between January and March 2007. Two separate pieces of data collection were undertaken.

First, a list of names of all HIV-infected eligible patients who were booked for group counseling (in the group counseling register) between January to June 2006 was documented, and checks made to see if these patients had appeared for group counseling and if they had started on ART.

Second, all patients who actually started on ART between January 1 st and June 30th were documented from the ART 
Register. Children who were 14 years and below and adult patients who had started on ART sometime previously in another facility and had transferred in to the study facility were excluded from the analysis. A record was made about who was alive and on ART six-months after start of therapy. In those patients, the weights at base-line, one month, 3months and 6-months after start of ART were recorded. Information on each patient was collected into a structured proforma, and this included age, gender, WHO clinical stage and weight in $\mathrm{kg}$ at initiation of therapy, at 1-month, 3-months and 6-months. Information was also collected on whether the ART site provided a nutritional package. Data were analyzed using an Excel spread sheet. Comparisons between categorical variables were made using chi-squared test and between numerical variables using student's t test.

\section{Ethical approval}

Specific data collected for this study did not include personal identifiers, and the Malawi National Health Science Research Committee provides general oversight and approval for the collection and use of routine programmatic data for monitoring and evaluation. The U.S. Centres for Disease Control and Prevention considered this study as programme evaluation, which does not constitute human-subjects research.

\section{Results}

\section{From booking to group counseling to start of ART}

Information about the process of group counseling was obtained from 5 sites: one of the sites (Andiamo Comfort Clinic did not perform group counseling, and instead carried out a series of individual counseling sessions). There were 738 adult HIV-infected eligible patients who had been booked for group counseling: this included 285 men and 453 women. Of these, 620 attended a group counseling session and 550 subsequently attended individual counseling and start of ART (Table 1). There were 188 (25.5\%) patients who were booked for group counseling who never started ART. Of these, 118 (16\%) dropped out between booking and group counseling, and a further $70(9.5 \%)$ dropped out between group counseling and start of ART. The proportion of men and women who dropped out at each stage was similar. Altogether $29 \%$ of men dropped out between group counseling and start of ART compared with $24 \%$ of women, although these differences did not achieve statistical significance.

\section{Weight gain on ART}

There were 629 adult patients (median aged 38 years, 66\% female) in the 6 sites who started on ART and were alive and on therapy six months later. Three sites provided a nutritional package of supplementation, while three did not. The weight gained in all patients, disaggregated by gender and in relation to whether nutritional supplementation was offered or not, is shown in Table 2. There was a steady increase in weight up to 6 months that was more than $10 \%$ of base-line body weight, and there were no significant differences in weight gain between patients started on ART in a nutritional supplementation site and in a site with no supplementation. For all patients starting ART, there were 78 patients in Stage $1 \& 2$ with a low CD4 count, 369 in Stage 3 and 182 in Stage 4. Weight gain in all patients, disaggregated by gender and
Table 1: Process of referral for group counseling, individual counseling and start of ART in men and women

\begin{tabular}{llll} 
& Male & Female & All patients \\
\hline $\begin{array}{l}\text { Number booked for } \\
\text { group counseling }\end{array}$ & 285 & 453 & 738 \\
$\begin{array}{l}\text { Number (\%) attended } \\
\text { group counseling }\end{array}$ & $231(81.1 \%)$ & $389(85.9 \%)$ & $620(84.0 \%)$ \\
$\begin{array}{l}\text { Number (\%) started } \\
\text { ART }\end{array}$ & $204(71.6 \%)$ & $346(76.4 \%)$ & $550(74.5 \%)$ \\
\hline
\end{tabular}

$\%$ refers to percentage of patients booked for group counseling

Table 2: Weight gain in adults starting antiretrovital therapy and alive on therapy six months later, disaggregated by gender and by whether nutritional supplementation was offered at a site or not.

\begin{tabular}{|c|c|c|}
\hline All Patients From 6 Sites: & Male & Female \\
\hline Patients ( $N=629$ ) & 213 & 416 \\
\hline Mean Baseline weight in $\mathrm{kg}$ & 53.9 & 47.5 \\
\hline $\begin{array}{l}\text { Mean cumulative weight gain } \\
\text { in } \mathrm{kg}(\%) \text { at } 1 \text { month }\end{array}$ & $+1.6(3.0 \%)$ & $+1.0(2.3 \%)$ \\
\hline $\begin{array}{l}\text { Mean cumulative weight gain } \\
\text { in } \mathrm{kg}(\%) \text { at } 3 \text { months }\end{array}$ & $+3.0(5.8 \%)$ & $+2.5(5.6 \%)$ \\
\hline $\begin{array}{l}\text { Mean cumulative weight gain } \\
\text { in } \mathrm{kg}(\%) \text { at } 6 \text { months }\end{array}$ & $+6.0(11.7 \%)$ & $+5.0(11.6 \%)$ \\
\hline
\end{tabular}

\begin{tabular}{lll}
\hline $\begin{array}{l}\text { Patients From } 3 \text { Sites With } \\
\text { Nutritional Supplementation: }\end{array}$ & Male & Female \\
\hline Patients ( $\mathrm{N}=276)$ & 75 & 201 \\
Mean Baseline weight in kg & 53.6 & 47.7 \\
$\begin{array}{l}\text { Mean cumulative weight gain in } \\
\mathrm{kg}(\%) \text { at } 1 \text { month }\end{array}$ & $+1.6(3.0 \%)$ & $+1.4(3.1 \%)$ \\
$\begin{array}{l}\text { Mean cumulative weight gain in } \\
\mathrm{kg}(\%) \text { at } 3 \text { months }\end{array}$ & $+2.8(5.6 \%)$ & $+2.8(6.2 \%)$ \\
$\begin{array}{l}\text { Mean cumulative weight gain in } \\
\mathrm{kg}(\%) \text { at } 6 \text { months }\end{array}$ & $+5.3(10.5 \%)$ & $+5.6(12.5 \%)$ \\
\end{tabular}

\begin{tabular}{|c|c|c|}
\hline $\begin{array}{l}\text { Patients From } 3 \text { Sites With No } \\
\text { Nutritional Supplementation: }\end{array}$ & Male & Female \\
\hline Patients (N = 353) & 138 & 215 \\
\hline Mean Baseline weight in $\mathrm{kg}$ & 54.0 & 47.3 \\
\hline $\begin{array}{l}\text { Mean cumulative weight gain in } \\
\mathrm{kg}(\%) \text { at } 1 \text { month }\end{array}$ & $+1.6(3.1 \%)$ & $+0.7(1.6 \%)$ \\
\hline $\begin{array}{l}\text { Mean cumulative weight gain in } \\
\mathrm{kg}(\%) \text { at } 3 \text { months }\end{array}$ & $+3.0(6.0 \%)$ & $+2.2(5.0 \%)$ \\
\hline $\begin{array}{l}\text { Mean cumulative weight gain in } \\
\mathrm{kg}(\%) \text { at } 6 \text { months }\end{array}$ & $+6.3(12.4 \%)$ & $+4.6(10.6 \%)$ \\
\hline
\end{tabular}

Legend: Standard deviations are not shown in the Table comparisons between different groups with each gender category carried out using student's t test - no significant differences found

in relation to the different WHO clinical stage categories is shown in Table 3. In all patients, there was a steady increase in weight up to 6 months. Within each gender category, there were no significant differences in the amount of weight gained between patients in different WHO Clinical Stages except for one comparison: in women there was a larger amount of weight gained at 6 months between those in Stage 4 (gained $6.1 \mathrm{~kg}$ ) compared with those in Stage 1 \&2 
Table 3: Weight gain in adults starting antiretroviral therapy and alive on therapy six months later, disaggregated by gender and Ssage of disease

\begin{tabular}{|c|c|c|}
\hline & Male & Female \\
\hline Patients in Stage $1 \& 2(\mathrm{~N}=78)$ & 27 & 51 \\
\hline Mean Baseline weight in $\mathrm{kg}$ & 58.8 & 52.0 \\
\hline $\begin{array}{l}\text { Mean cumulative weight gain in } \mathrm{kg} \\
(\%) \text { at } 1 \text { month }\end{array}$ & $+1.5(2.6 \%)$ & $+0.9(1.8 \%)$ \\
\hline $\begin{array}{l}\text { Mean cumulative weight gain in } \mathrm{kg} \\
(\%) \text { at } 3 \text { months }\end{array}$ & $+2.5(4.4 \%)$ & $+2.3(4.5 \%)$ \\
\hline $\begin{array}{l}\text { Mean cumulative weight gain in } \mathrm{kg} \\
(\%) \text { at } 6 \text { months }\end{array}$ & $+4.5(7.85 \%)$ & $+3.3(6.7 \%)$ \\
\hline Patients in Stage $3(\mathrm{~N}=369)$ & 113 & 256 \\
\hline Mean Baseline weight in $\mathrm{kg}$ & 52.5 & 47.5 \\
\hline $\begin{array}{l}\text { Mean cumulative weight gain in } \mathrm{kg} \\
(\%) \text { at } 1 \text { month }\end{array}$ & $+1.5(3 \%)$ & $+1.1(2.4 \%)$ \\
\hline $\begin{array}{l}\text { Mean cumulative weight gain in } \mathrm{kg} \\
(\%) \text { at } 3 \text { months }\end{array}$ & $+3.2(6.4 \%)$ & $+2.3(5.2 \%)$ \\
\hline $\begin{array}{l}\text { Mean cumulative weight gain in } \mathrm{kg} \\
(\%) \text { at } 6 \text { months }\end{array}$ & $+6.2(12.3 \%)$ & $+5.0(11.2 \%)$ \\
\hline Patients in Stage $4(\mathrm{~N}=182)$ & 73 & 109 \\
\hline Mean Baseline weight in $\mathrm{kg}$ & 54.1 & 45.3 \\
\hline $\begin{array}{l}\text { Mean cumulative weight gain in } \mathrm{kg} \\
(\%) \text { at } 1 \text { month }\end{array}$ & $+1.7(3.4 \%)$ & $+1.0(2.3 \%)$ \\
\hline $\begin{array}{l}\text { Mean cumulative weight gain in } \mathrm{kg} \\
(\%) \text { at } 3 \text { months }\end{array}$ & $+2.9(5.6 \%)$ & $+2.9(6.9 \%)$ \\
\hline $\begin{array}{l}\text { Mean cumulative weight gain in } \mathrm{kg} \\
(\%) \text { at } 6 \text { months }\end{array}$ & $+6.2(12.3 \%)$ & $+6.1(14.7 \%)$ \\
\hline
\end{tabular}

Legend: Standard deviations are not shown in the Table -comparisons between different groups within each gender category carried out using student's t test - the only significant difference is at 6 months between women in Stage 1\&2 compared with women in Stage 4 $(p<0.05)$

(gained $3.3 \mathrm{~kg}$ ) $-\mathrm{p}<0.05$.

\section{Discussion}

This study shows that about one quarter of HIV-infected patients assessed as eligible for ART dropped out between the assessment and booking for group counseling and the start of ART, with the drop out being slightly higher for men than for women. The reasons for this in Malawi are not known, but possible reasons include:- death while waiting for ART, as has been experienced in South Africa ${ }^{5}$, patients deciding to go to another treatment facility or patients deciding that life long treatment is not a good option and seeking alternative therapy. A more comprehensive qualitative study of patients who drop out of the process is needed to develop effective strategies to address these issues.

The study also shows that in those patients who started ART and remained alive and on therapy six months later, weight gain was substantial. Both men and women overall experienced a gain in weight of greater than $10 \%$ of their base-line body weight. There were no differences in overall weight gain in patients from a site that provided nutritional supplementation compared with a site that had no such support. Although weight gain appeared to be higher in patients with clinical Stage 3 and 4 compared with Stage $1 \& 2$, this was only significant at 6 months between women in Stage 1\&2 and women in Stage 4. The causes of weight loss and wasting in HIV-infected patients are multi-factorial and seem to be a complex interplay of loss of body fat and lean body mass 6 . The degree of gain in lean body mass and in body fat cannot be deduced from this study.

This was an operational study and has all the limitations of such research. We were not able to document from the records which patients were taking nutritional supplementation, or whether they complied with such an intervention. The lack of difference in weight gain between patients from nutritionally supported sites and those with no support may have been due to few patients actually being offered nutritional supplementation. We recorded weights from master cards and therefore have no way of validating whether these were accurate or not. Nevertheless, the findings do reflect the general belief that patients gain weight well on ART and that this continues progressively up to 6 months. We do not know what happens after 6-months, and we also do not know what happens to weight change in patients who die on ART. There is a significant association between severe immunodeficiency, low body mass index and early mortality on ART ${ }^{7,8,9}$, and we need proper controlled trials to determine whether nutritional supplementation given at the same time as ART can reduce such mortality.

\section{Acknowledgement}

We thank an anonymous donor who supported the financial aspects of this study.

\section{References}

1. HIV Unit, Ministry of Health. ART in the public sector in Malawi - results up to 31st December, 2006. Lilongwe, Malawi.

2. Libamba E, Makombe S, Harries AD, et al. Scaling up antiretroviral therapy in Africa: learning from tuberculosis control programmes - the case of Malawi. Int J Tuberc Lung Dis 2005; 9: $1062-1071$.

3. Ministry of Health. Treatment of AIDS. Guidelines for the use of antiretroviral therapy in Malawi. Second Edition, April 2006. Lilongwe, Malawi.

4. Libamba E, Makombe S, Mhango E, et al. Supervision, monitoring and evaluation of nationwide scale up of antiretroviral therapy in Malawi. Bulletin World Health Organization 2006; 84: 320 - 326.

5. Lawn SD, Myer L, Harling G, Orrell C, Bekker L-G, Wood R. Determinants of mortality and nondeath losses from an antiretroviral treatment service in South Africa: implications for program evaluation. Clin Infect Dis 2006; 43: 770 - 776.

6. Mangili A, Murman DH, Zampini AM, Wanke CA. Nutrition and HIV infection: review of weight loss and wasting in the era of highly active antiretroviral therapy from the nutrition for healthy living cohort. Clin Infect Dis 2006; 42: 836 - 842 .

7. The antiretroviral Therapy in Lower Income Countries (ARTLINC) Collaboration and ART Cohort Collaboration (ART-CC) groups. Mortality of HIV-1-infected patients in the first year of antiretroviral therapy: comparison between low-income and highincome countries. Lancet 2006; $367: 817$ - 824.

8. Lawn SD, Myer L, Orrell C, Bekker L-G, Wood R. Early mortality among adults accessing a community-based antiretroviral service in South Africa: implications for programme design. AIDS 2005; 19: $2141-2148$

9. Zachariah R, Fitzgerald M, Massaquoi M, et al. Risk factors for high early mortality in patients on antiretroviral treatment in a rural district of Malawi. AIDS 2006; 20: 2355- 2360. 